\title{
Influence of Transformational Leadership, Organizational Culture and Trust on Organizational Commitment
}

\author{
Rianto Ritonga \\ Post Graduate Program \\ Pakuan University, Bogor, Indonesia
}

\begin{abstract}
The purpose of this study is to determine whether there is a direct positive effect of transformational leadership, organizational culture and trust in organizational commitment of the teachers in Public Occasional School located in North Jakarta. The target population of this study is public school teachers at the respective school totaling 200 teachers who constituted as the framework of the population. The number of samples taken for this study is 133 teachers. This study applies path analysis. The research results show that there is a direct positive effect of transformational leadership on organizational commitment, organizational culture on the organizational commitment, trust on organizational commitment, transformational leadership on trust, and organizational culture on trust.
\end{abstract}

Keywords: organizational commitment, transformational leadership, organizational culture, trust.

\section{INTRODUCTION}

The success of a learning activity can be determined by various factors, both of which come in the form of interest and attention of students as well as the outside factors coming from the teacher. In the process of teaching and learning, in order to produce the expected results, the two sides both students and teachers need to have the attitude, ability and skills that support the learning process to achieve the learning objectives. Therefore, a teacher is required to have a qualification, competence and good performance as a professional teacher in performing their duties to achieve maximum results. Effective teachers are expected to perform the duties and functions of professionals. To be able to perform their duties professionally, necessary requirements such as academic competence, personal maturity, attitude, dedication, and most of all commitment must be possessed. But in reality, there are some teachers who have not been able to work optimally complying with the demands of work so resulting in less professional manner both in carrying out their duties as educators in school and becoming excellent in other fields supporting the functions and duties as educators for professional development.

Based on data from the results of a preliminary survey conducted on March 2014, the results of the analysis of questionnaire data on the organizational commitment of vocational school teachers in Jakarta concludes: $58 \%$ of teachers are reluctant to remain as a member of the organization of the school, 54\% of teachers are difficult to maintain loyal attitude to school, 54\% of teachers have problems in performing the task / job well, 54\% of teachers are hard to involve in any activities held in school and 58\% of teachers show less pride to be part of the school organization. Problems of teachers' organizational commitment can occur if the leadership, in this regard the principal of the school, does not give consideration to the teachers who require the attention of the leader by listening to the aspirations of the teachers in any job related problems. Several factors are thought to influence the organizational commitment among others are internal factors such as emotional intelligence, individual characteristics, abilities, personality, motivation, respect, trust as well as job satisfaction and external factors including infrastructure, empowerment, leadership, organizational culture, organizational climate, government policy, team work. Among these factors, teachers' perceptions about leadership, organizational culture and trust in relation to the organizational commitment are very interesting to study. With that background, the researcher intends to examine what are the factors that affect organizational commitment among Public Vocational School teachers in North Jakarta? 


\section{LITERATURE REVIEW}

According to Robbins (2008) organizational commitment is the degree to which an employee identifies with a particular organization and its goals and wishes to maintain membership in the organization. Schermerhorn (2011) defines organizational commitment is the loyalty of an individual to the organization. Colquitt, Lepine and Wesson (2011) stated that organizational commitment is defined as the desire on the part of an employee to be a member of the organization. Based on the concept mentioned above, it can be synthesized that organizational commitment is the identification and attitudes towards the organization with the desire to be fully involved in performing the task / work to achieve organizational goals as well as his desire to remain as a member of the organization.

Nelson \& Quick (2012) explain leadership in organizations is the process of guiding and directing the behavior of people in the work environment. Colquitt, Lepine and Wesson (2011) define that leadership involves a person's ability to use his power and influence over their followers that want to run their activities in order to achieve the desired goal. Schein (2004) differentiates leadership into two: (1) transactional leadership, and (2) transformational leadership. Transactional leadership is leadership that has a contractual nature between leaders and followers. Leaders need followers and offers exchanger loyalty of followers. Followers are willing to cooperate for getting reward. A transformational leader reshaped followers by creating a change in goals, values, needs, beliefs, and aspirations. The leader completes this change by appealing concept of self, identity, and values of followers. He also explained that transformational leadership behaviors involve four characteristic namely, (1) inspirational motivation, (2) idealistic influence, (3) individual consideration, and (4) intellectual stimulation. According to Gibson, Ivancevich, and Donnelly (2011) define that transformational leadership is the ability to inspire and motivate followers to achieve the greater result than originally planned for the internal reward.

Based on the exposure draft of the above it can be synthesized that transformational leadership is the behavior of a leader who is able to influence followers to achieve the vision, mission and common goals which is the alignment of leaders, followers and the organization through the influence of the idealism of teachers that bring a sense of pride and confidence, inspire and motivate, stimulate creativity and innovation, treat person individually and always train and provide guidance to his followers. Strong transformational leadership from the principal will be able to affect all members, especially the teachers who lead the process of change towards increasing better commitment. The leaders can be effective because of their influence on motivating employee. Leaders can raise the performance and employee satisfaction in achieving personal goals of employees and looking for a way or path in achieving these objectives to increase commitment to the organization.

Leaders, in this case the principal creating a climate for the organization and its values will directly or indirectly affect the commitment of the teachers in the organizations they serve. In an environment that is relatively not too broad, the principal should serve as a model in an organization committed to setting the standard for performance, motivating teachers, and becoming a symbol for the external environment. Thus, to transmit values to the behavior of the teacher, the principal should reinforce the behavior through incentives, rewards, awards, celebration, a symbolic act, and so forth. By being a role model or example, the principal and teachers will demonstrate their commitment to the organization. In accordance with the framework above, it is expected that there will be a positive direct influence of transformational leadership to teachers' organizational commitment.

According to Schermerhorn (2011) organizational culture is the system of shared actions, values, and beliefs that develops within an organization and guides the behavior of its members. Organizational culture is understood as the disclosed system in the organization in the form of actions, values, and beliefs in such a way that it becomes a reference the behavior of members within the organization. According Colquitt, Lepine, and Wesson (2011) organizational culture is defined as the shared social knowledge within an organization regarding the rules, norms, and values that shape the attitudes and behaviors of its employees. With such definition, organizational culture is nothing but a social understanding that is internalized members of the organization and is believed to be the rules, norms, attitudes and behaviors that define the members of the organization. Kreitner and Kenicki (2010) define that organizational culture is the set of shared values and beliefs that underlie a company's identity. For Kreitner and Kenicki organizational culture is a set of values and beliefs internalized and becomes the foundation for the establishment of identity within the institution or organization. 
Robbins and Judge (2011) define that organizational culture refers to a system of shared meaning held by members that distinguishes the organization from other organizations. Accordingly, organizational culture is an internalized value system firmly held by its members to distinguish certain organizations from other organizations. Based on the exposure draft of the above, it can be synthesized that organizational culture is the values, norms and beliefs that are widely shared and understood by all members of an organization that has become a habit and serves as guidelines of working implementation among members in the organization.

Organizational culture can become facilitators for the organizational commitment both for members of organization and those associated with the organization. In the school environment, good organizational culture will offer trust and confidence for stakeholders to both parents of school students and other organizations. School as an institution serving education realizes the importance of teachers with good organizational culture in terms of providing good service, warmth, openness to feedback, and actively solve the problem. All will make the organization's members are attached and loyal to the school. Favorably environmental conditions for a fun job with co-workers automatically will foster organizational commitment of teachers. In accordance with the framework above, it is expected that there will be a positive direct influence of organizational culture on organizational commitment.

Trust is essential in the organization as without trust is not possible to mold harmonious relationship between leaders and subordinates. Experts are trying to define trust based on the conditions and point of view. According Colquitt, Lepine, and Wesson (2011) trust is the willingness to be vulnerable to a trustee based on positive expectations about the trustee's actions and intentions. For Colquitt et al., trust is the desire to give authority to the trustee in such a way, through actions and good intentions. For Mullins (2005) trust is one of the employee's needs that must be met to induce a sense of joy in work. McShane and Von Glinow (2010) define that trust refers to the positive expectations of a person against another person in it is certainly risky. According to Robbins and Judge (2011) trust is positive expectation that another will not through words, action, or decision, act opportunistically.

Based on the concept of exposure mentioned above, it is synthesized that trust is a positive desire and hope and authority given to the person or group believed on the basis of mutual respect through positive actions and intentions of the person who authorized it. Building trust in accordance with the principles of the granted authority within an organization can help members to develop ideas quickly, to take risk, to innovate in demonstrating organizational commitment. Trust in an organization is very important in supporting the commitment of teachers due to their belief in a sense of responsibility, solidarity, and ownership of the entire organization. Trust will also encourage democratic atmosphere and enhance the effectiveness of the entire organization as a real sign of increasing the commitment to the organization. Similarly, at Public Vocational School in North Jakarta, the trust factor becomes one of the key factors to increase the commitment of the teachers. In a typical devotion atmosphere of school run by the regional government, it is needed a high level of trust among members and between members and the principal. In accordance with the above framework, it is expected there is significant positive direct effect of trust to teachers' organizational commitment.

Based on the formulation of the problem and the theoretical framework, the research hypothesis is formulated as follows:

1. Transformational leadership has a direct positive effect on organizational commitment.

2. Organizational culture has a direct positive effect on organizational commitment

3. Trust has a direct positive effect on organizational commitment.

4. Transformational leadership has a direct positive effect on trust.

5. Organizational culture has a direct positive effect on trust.

\section{Methodology}

This study applies Sequential Explanatory Design Mixed Method where quantitative study is ahead of qualitative study to examine the relationship between variables tested in the study using three independent variables through data obtained from questionnaires. The independent variable is Transformational Leadership $\left(\mathrm{X}_{1}\right)$ Organizational Culture, $\left(\mathrm{X}_{2}\right)$, and Trust $\left(\mathrm{X}_{3}\right)$, while the dependent variable is Organizational Commitment $(\mathrm{Y})$. 
The population in this study is 133 randomly selected public vocational school teachers in North Jakarta, Indonesia.. The validity test is using Product Moment. The reliability test is using Cronbach alpha. Normality test is performed by using Lilliefors test. The result of test indicates all requirements are met for further testing. Path analysis is used to determine (1) the direct positive influence of transformational leadership toward organizational commitment (2) direct positive influence of organizational culture toward organizational commitment (3) direct positive influence of trust toward organizational commitment (4) the direct positive influence of transformational leadership trust (5) direct positive influence of organizational culture toward trust..

\section{RESUlT AND DISCUSSION}

The finding of this study revealed that transformational leadership, organizational culture, and trust had a positive influence on organizational commitment as depicted on the following table.

Table1. Path Analysis Results

\begin{tabular}{|l|l|l|l|l|l|}
\hline No. & Path & Correlation Coefficient & T test & T Table & Note \\
\hline 1. & $\mathrm{X}_{1}-\mathrm{Y}$ & 0.66 & 10.06 & 1.98 & Significant \\
\hline 2. & $\mathrm{X}_{2}-\mathrm{Y}$ & 0.79 & 14.93 & 1.98 & Significant \\
\hline 3. & $\mathrm{X}_{3}-\mathrm{Y}$ & 0.73 & 12.09 & 1.98 & Significant \\
\hline 4. & $\mathrm{X}_{1}-\mathrm{X}_{3}$ & 0.87 & 19.76 & 1.98 & Significant \\
\hline 5. & $\mathrm{X}_{2}-\mathrm{X}_{3}$ & 0.86 & 19.67 & 1.98 & Significant \\
\hline
\end{tabular}

In the structural model, transformational leadership $\left(\mathrm{X}_{1}\right)$ had direct positive significant influence on organizational commitment $(\mathrm{Y})$ with correlation coefficient $=0.661(\mathrm{t}=10.06 ; \mathrm{p}<0,01)$, Organizational culture $\left(\mathrm{X}_{2}\right)$ had direct positive effect toward organizational commitment $(\mathrm{Y})$ with correlation coefficient $0.993(\mathrm{t}=14.93 ; \mathrm{p}<0.01)$. Trust $\left(\mathrm{X}_{3}\right)$ had direct positive effect toward organizational commitment $(\mathrm{Y})$ with correlation coefficient $0.725(\mathrm{t}=12.09 ; \mathrm{p}<0.01)$. Transformational leadership $\left(\mathrm{X}_{1}\right)$ had direct positive effect toward trust $\left(\mathrm{X}_{3}\right)$ with correlation coefficient $0.867(t=19.76 ; \mathrm{p}<0.01)$. Organizational culture $\left(\mathrm{X}_{2}\right)$ had direct positive effect toward trust $\left(\mathrm{X}_{3}\right)$ with correlation coefficient $0.1864(\mathrm{t}=19.67 ; \mathrm{p}<0.01)$.

Hypothesis testing results indicate that transformational leadership positively affects organizational commitment. This is in line with the theory put forward by Bass and Riggio (2006) that transformational leadership involves followers who are inspired to commit to a shared vision and goals of the organization, challenges followers to become innovative problem solvers, and develops followers' leadership through training, mentoring as well as provides challenge and support. The transformational leader is able to encourage his followers to produce performance beyond the expected results which will further enhance the organizational commitment of the followers. Thus the results of this study further support the results of previous studies on the positive influence of transformational leadership to organizational commitment.

Hypothesis testing results show that organizational culture positively affects organizational commitment. This is in line with the theory put forward by Robbins and Judge (2011) stated that the organizational culture refer to a system of shared meaning held by members that distinguishes the organization from other organizations. Thus the results of this study further support the results of previous studies on the positive influence of organizational culture to organizational commitment.

Hypothesis testing results show that trust positively affects organizational commitment

This is in line with the theory put forward by McShane and Von Glinow (2010) that trust refers to the positive expectations of a person against another person in it is certainly risky. It is also a reciprocal activity, that is, to gain the trust of others, one also must do it to others. The employees will be impartial and accountable for the work of the institution / company when employees put their trust in leaders. Thus the results of this study further support the results of previous studies on the positive influence of trust to organizational commitment.

Hypothesis testing results indicate that transformational leadership positively affects trust.

This is in line with the theory put forward by Qolquitt, Lepine and Wesson (2009) that transformational leadership involves followers who are inspired to commit to a shared vision that gives meaning to their work and in line with that serve as role models to help followers developing their potential and ability to see the problem with a new perspective. Transformational leaders also raise awareness of the importance of achieving high yields and raise the confidence of followers that 
the results could be achieved. Thus the results of this study further support the results of previous studies about the positive influence of transformational leadership to trust.

Hypothesis testing results show that organizational culture positively affects trust

This is in line with the theory put forward by Gibson (2012) that organizational culture is what employees perceive and how this perception creates a shared sense and pattern of beliefs, values, and expectations. For Gibson organizational culture is nothing but what is internalized employees and how it gave birth to the awareness and appreciation of the pattern of beliefs, values, and expectations are employees.

Thus the results of this study further support the results of previous studies on the positive influence of organizational culture to trust.

The result of qualitative studies in the following sequence also confirms these findings.

\section{Conclusion}

Results of this study conclude:

1. There is a direct, positive, significant influence between transformational leadership and organizational commitment. Strong transformational leadership will have a considerable influence on the improvement of organizational commitment as indicated by a correlation of coefficient $\mathrm{o}=$ 0.660 and coefficient of determination $=43.6 \%$.

2. There is a direct, positive, significant effect of organizational culture on organizational commitment. Good organizational culture will have a considerable influence on the improvement of organizational commitment as indicated by correlation coefficient $=0.794$ and coefficient of determination $=63.0 \%$.

3. There is a direct, positive, significant effect of trust to organizational commitment. High trust will have a considerable influence on the improvement of organizational commitment as indicated by correlation coefficient $=0.726$ and coefficient of determination $=52.7 \%$

4. There is a direct, positive, significant effect of transformational leadership on trust. Strong transformational leadership will have a considerable influence on the increase of trust as indicated by correlation coefficient $=0.865$ and coefficient of determination $=74.9 \%$.

5. There is a direct, positive, significant effect of organizational culture on trust. Good organizational culture will have a considerable influence on the increase of trust. This is indicated by a correlation coefficient $\mathrm{o}=0.864$ and coefficient of determination $=74.7 \%$.

\section{REFERENCES}

Colquitt., Jason A., Jeffery A. Lepine., and Michael J. Wesson. Organizational Performance and Commitmen in the Workplace. New York: McGraw-Hill, 2009.

Gibson, J.L., J.M. Ivancevich, J.H. Donnelly, R. Konopaske. Organizations: Behavior, Structure and Process. New York: McGraw-Hill, 2012.

Kinicki, A., R. Kreitner, Organizational Behavior, Key Concepts, Skills, and Best Practices. New York: McGraw-Hill, 2010

McShane, Steven L., and M.A. Von Glinow. Organizational Behavior, Emerging Realities For The Workplace Revolution, New York: McGraw-Hill, 2010

Mullins, L.J., Management and Organization, seventh edition, Pearson Education Limited, 2005

Nelson, Debra L. \& James Campbell Quick. Principles of Organizational Behavior Realities and Challenges, Sixth Edition. Singapore: Mc Graw-Hill, International Edition Inc, 2012.

Robbins, Stephen P., Timothy A. Judge. Organizational Behavior. New Jersey: Pearson Prentice Hall, 2011.

Robbin, Stephen P., Management, Prentige Hall, 2008

Schermerhorn, Hurn, Osborn, and UHL-Bien. Organizational Behavior. New Jersey: John Wiley \& Sons, Inc., 2011

Schein, Edgar H., Organizational Culture and Leadership, Third Edition, San Fransisco: Jossey-Bass Publisher, 2004. 